\title{
Mycoprotein: environmental impact and health aspects
}

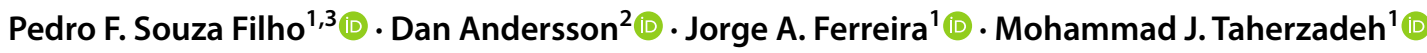

Received: 4 May 2019 / Accepted: 5 September 2019 / Published online: 23 September 2019

(c) The Author(s) 2019

\begin{abstract}
The term mycoprotein refers to the protein-rich food made of filamentous fungal biomass that can be consumed as an alternative to meat. In this paper, the impact caused by the substitution of animal-origin meat in the human diet for mycoprotein on the health and the environment is reviewed. Presently, mycoprotein can be found in the supermarkets of developed countries in several forms (e.g. sausages and patties). Expansion to other markets depends on the reduction of the costs. Although scarce, the results of life cycle analyses of mycoprotein agree that this meat substitute causes an environmental impact similar to chicken and pork. In this context, the use of inexpensive agro-industrial residues as substrate for mycoprotein production has been investigated. This strategy is believed to reduce the costs involved in the fungal cultivation and lower the environmental impact of both the mycoprotein and the food industry. Moreover, several positive effects in health have been associated with the substitution of meat for mycoprotein, including improvements in blood cholesterol concentration and glycemic response. Mycoprotein has found a place in the market, but questions regarding the consumer's experience on the sensory and health aspects are still being investigated.
\end{abstract}

Keywords Alternative protein $\cdot$ Amino acids $\cdot$ Human health $\cdot$ Life cycle analysis $\cdot$ Meat substitute $\cdot$ Mycoprotein

\section{Introduction}

During the past 60 years, the global agricultural production has been thoroughly improved to meet the demands of a rapidly growing population. With an increase of just $10 \%$ in the amount of agricultural land used, the global food production doubled (FAO 2010). This strategy, however, together with changes in the lifestyle, poverty, population pressures, and urbanization, has deeply affected the human diet and health (Augustin et al. 2016).

The food sector constitutes one of the largest contributors to both local and global environmental impact and resource use. Several studies associate losses of biodiversity and degradation of ecosystems with food production (Dunne et al.

Pedro F. Souza Filho

pfsfilho@gmail.com

1 Swedish Centre for Resource Recovery, University of Borås, Borås, Sweden

2 Faculty of Caring Science, Work Life and Social Welfare, University of Borås, Borås, Sweden

3 Present Address: Laboratory of Biochemical Engineering, Chemical Engineering Department, Federal University of Rio Grande do Norte, Natal 59078-970, Brazil
2002; Röös et al. 2013; Tscharntke et al. 2012). It is estimated that between 70 and $85 \%$ of the water footprint caused by human activities is associated with the agricultural activity (Smetana et al. 2015). Moreover, more than $30 \%$ of the total greenhouse gases (GHG) emitted by humans are a side product of the agricultural sector, with more than half of it (approximately 18\%) being connected with the production of meat (Smetana et al. 2015; Steinfeld et al. 2006).

The global population is estimated to decelerate its growth, reaching a plateau at around 9 billion people near the middle of this century; providing food to this population will add extra pressure to the food system (Godfray et al. 2010). These facts are regarded as challenges to the future of the food and nutrition security, and led to the proposition of new food systems to improve public health. The propositions are based on the concept of a sustainable diet, i.e., a diet with reduced environmental impact and that contributes to the elimination of poverty, food and nutrition insecurity, and poor health outcomes (Johnston et al. 2014). The concept is similar to the Food and Agriculture Organization (FAO) definition of a climate-smart agriculture, a system that fights climate changes while consequently enhancing food security, as both are closely related (FAO 2010). It is part of a sustainable diet to reduce the consumption of meat: 
livestock production represents the largest emitter of methane as well as the largest user of land resources, causing land degradation and deforestation (FAO 2010). It is important to notice that the food products used to replace the meat should provide the same nutritional benefits, with less harm to the environment. The products that fit these demands are known as meat substitutes, meat analogues, meat replacers, or meat alternatives (Hoek et al. 2011) and they can be based on plant (e.g. soy, pea, and oat), animal (e.g. milk and insects) or microbial products (e.g. mycoprotein) (Smetana et al. 2015).

Socially, the consumption of meat has been justified by the so-called 4Ns-the belief that it is natural, normal, necessary, and/or nice (Piazza et al. 2015). However, ethical and environmental concerns have recently induced a rapid expansion of the meat substitute market (Godfray et al. 2018), which is predicted to have an annual turnover of $\$ 6$ billion in 2022 (Ritchie et al. 2017). The main reason for the substitution of the meat in a consumer's diet is the possible nutritional benefit it can bring. Several studies have reported that red meat consumption may increase mortality (Pan et al. 2012; Rohrmann et al. 2013; Snowdon et al. 1984). Yet, to remove the meat from the diet, the taste and variety of the options are also considered (Asgar et al. 2010). Elzerman et al. (2011) reported out that replacing meat in a nonvegetarian's diet is easier when the meat substitute fits in a meal, compared to when it is tasted separately. Therefore, a meat alternative does not necessarily need to resemble meat in texture, taste, and flavor, but it needs to look like meat. In this context, the substitution of meat by mycoprotein is considered a more realistic scenario than the change to protein-rich plants because mycoprotein is more similar to meat, easing the consumers' acculturation process (Raats 2007). A comparison of different meat and meat alternative options is presented in Table 1 .

Mycoprotein refers to the proteinaceous food obtained from filamentous fungal biomass which can be used for human consumption. Mushrooms and truffles, also belonging to the Fungi Kingdom, have been part of the diet of many cultures thanks to their pleasant taste (Boland et al. 2013). However, they are not considered good meat substitutes because of their low content of proteins. Rapid growth and high protein content, on the other hand, make filamentous fungi important potential sources of protein for food (Anupama and Ravindra 2000). These fungi have been consumed for many years by humans as components of fermented food, aiming to prolong the shelf-life, reduce the volume, shorten the cooking time, and improve the nutritive value of the food (Nout and Aidoo 2002). In Europe, Penicillium roquefortii and Penicillium camembertii are used in the production of blue (Roquefort, Gorgonzola) and soft-ripened (Camembert and Brie) cheese, respectively. In Asia, Monascus purpureus is used in the production of red yeast rice; Aspergillus oryzae ferments soybeans to produce hamanatto, miso and shoyu (Moore and Chiu 2001). Alternatively, the filamentous fungal biomass can be processed and used as food, that is, mycoprotein. Mycoprotein has been designated as GRAS - Generally Recognized As Safe-by the Food and Drug Administration (FDA) in the US since 2002 (Denny et al. 2008).

Presently, one company (Quorn ${ }^{\circledR}$, Marlow Foods, UK) commercializes mycoprotein products in supermarkets of 19 countries (Marlow Foods Ltd 2019). The fungus Fusarium venenatum is grown in a defined medium, treated to have its RNA content reduced, and added egg albumen, color and flavor compounds to mimic the texture and aspect of meat (Wiebe 2002). Research on appearance, texture, and mouthfeel of mycoprotein is limited to that associated with the production of Fusarium venenatum mycelial biomass. The present production method is costly, what results in market prices for mycoprotein similar to those of meat (Ritchie et al. 2017). The reduction of the cost involved in the production is one of the challenges to encourage the consumption of mycoprotein. Public awareness of the health and environmental benefits can also contribute to popularize mycoprotein. The present review provides a current environmental and health perspective of mycoprotein and future research avenues to encourage its production and consumption.

\section{Environmental aspects}

According to Siegrist and Hartmann (2019), the consumer's behavior is influenced by both the knowledge about the nutritional value and the perception of the environmental impact caused by the food. Therefore, the first step to popularize the consumption of the meat substitutes is to increase the public knowledge about the environmental impact of their dietary habits. The literature about life cycle analyses (LCA) of mycoprotein is scarce. Yet, they agree that mycoprotein causes less impact to the environment than beef. Finnigan et al. (2010) used an LCA to compare Quorn ${ }^{\circledR}$ mince with beef mince and determined that, considered the same weight, the meat alternative generates only $48 \%$ of the global warming potential the animal protein causes. Uncertainties about the required amounts of glucose and egg albumen in the formulation of the mycoprotein product can increase this value to $60 \%$. This study limited the system boundaries from the production of the raw materials to the factory gate.

Smetana et al. (2015) compared the environmental impact of mycoprotein produced from sugar beet molasses to chicken, lab grown meat, and dairy-, insect-, gluten- and soy based options. The bases used for the comparison were the weight, the calorific energy value, and the content of digestible bulk protein of each product. This was the first study involving mycoprotein to evaluate local and regional impact categories such as acidification, eutrophication and 


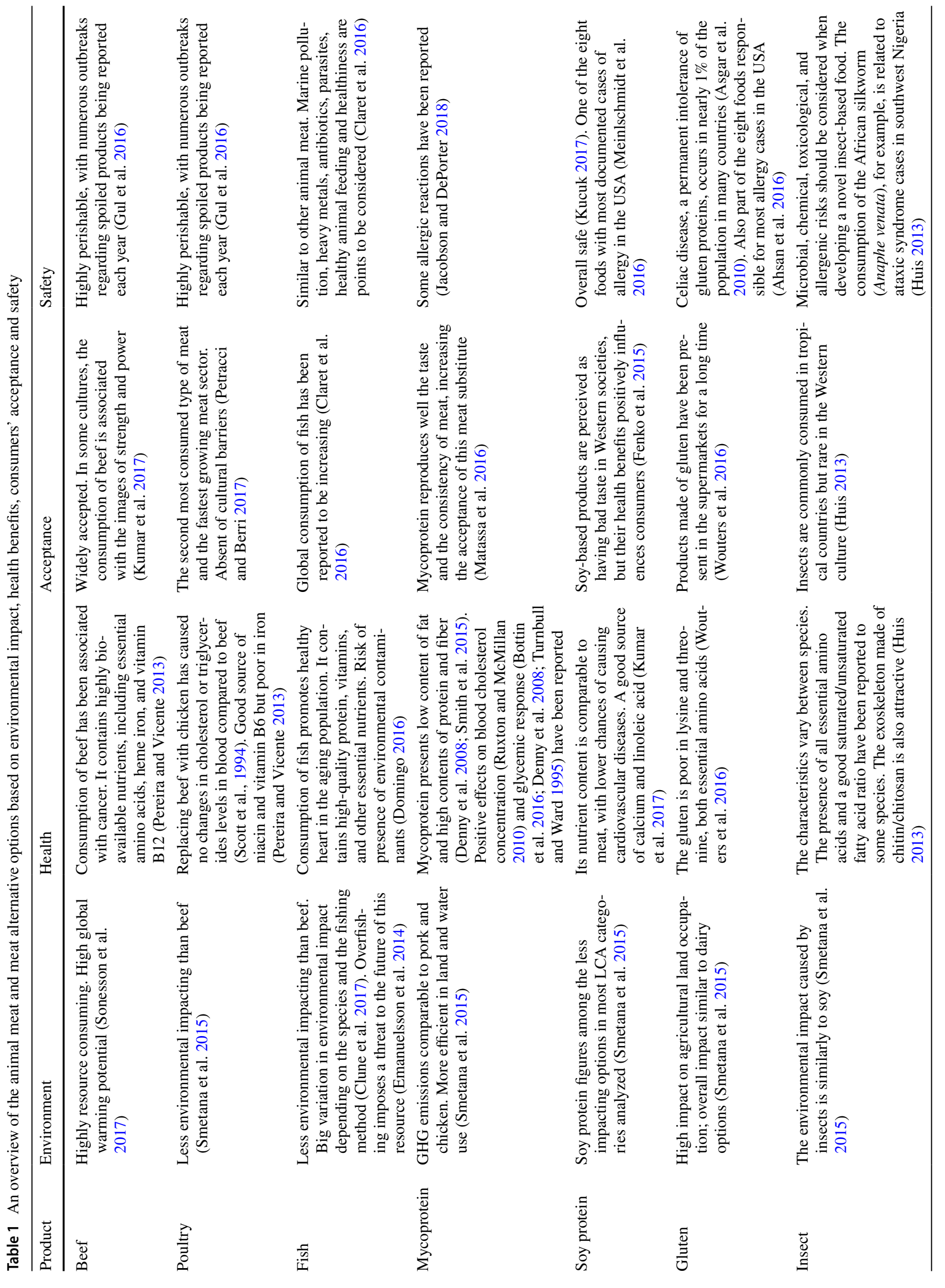




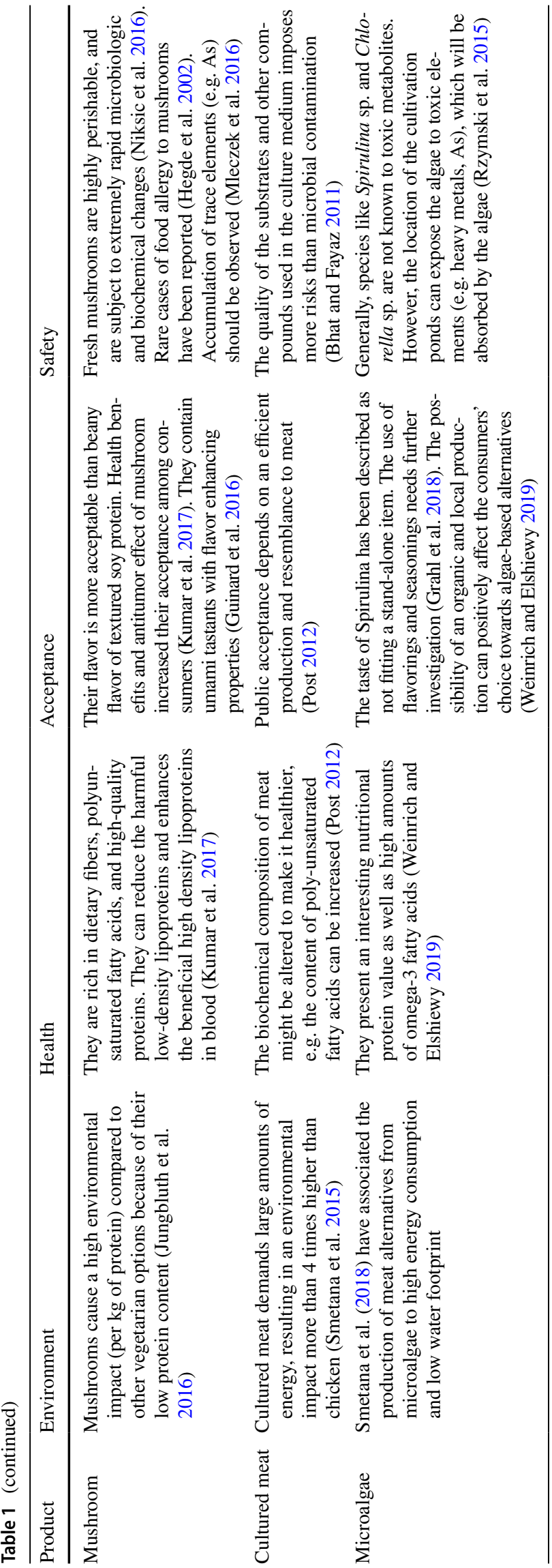

land use. According to the authors, the production of $1 \mathrm{~kg}$ of mycoprotein and $1 \mathrm{~kg}$ of chicken meat has similar impacts; and they are only lower than cultured meat (a technology in its early stages of development). Almost half of the mycoprotein overall impact (45\%) comes from the mycoprotein processing; other $25 \%$ is the result of the frying at consumer, and $21 \%$ is associated with the components used in its production (10\% for the egg white and $11 \%$ for the nitrogen fertilizer needed to grow the crops used as fungal substrate).

In the same work, the global warming potential for the mycoprotein has been determined to be $5.55-6.15 \mathrm{~kg} \mathrm{CO}_{2 \mathrm{eq}}$ per kg of fungal product. Comparatively, chicken and pork have a global warming potential of 2-4 and 4-6 $\mathrm{kg} \mathrm{CO}_{2 \text { eq }}$ per $\mathrm{kg}$ of meat, respectively. When comparing the environmental impact of mycoprotein considering the calorific energy value and the content of digestible proteins, mycoprotein performed poorly. Only the impact of the cultured meat was superior to the mycoprotein.

In another work, Smetana et al. (2018) have reported the energy, land and water used in the production of meat substitutes. Mycoprotein figures among the most efficient alternatives when considering land $\left(<2 \mathrm{~m}^{2} \mathrm{a} / \mathrm{kg}\right.$; compared to 5-7 $\mathrm{m}^{2} \mathrm{a}$ for chicken and 7-8 $\mathrm{m}^{2}$ a for pork) and water use $(\sim 500$ $\mathrm{L} / \mathrm{kg}$ ). For the energy consumption category, mycoprotein was as efficient as dairy alternatives $(15-20 \mathrm{kWh} / \mathrm{kg})$, but less efficient than vegetables and insects (less than $10 \mathrm{kWh} /$ $\mathrm{kg}$ and $5-15 \mathrm{kWh} / \mathrm{kg}$, respectively).

The use of LCA as a tool to compare the protein sources is important to provide information about the environmental impact of the food to the consumers. However, the definition of a functional unity for comparison of the food products still needs validation. Parameters such as $\mathrm{kg}$ of product, $\mathrm{kg}$ of protein, and $\mathrm{kg}$ of protein corrected by its digestibility score have been studied (Sonesson et al. 2017). Additionally, when focusing the comparisons on the protein content, other nutrients are neglected. In a preliminary study, Jungbluth et al. (2016) have determined the impacts of a complete home-cooked meal prepared with meat alternatives based on the Swiss ecological scarcity method from 2013. The meals were planned to provide a good balance of different nutrients. The mycoprotein option performed the worst among the vegetarian options studied, but was better than the meat and fish options used for comparison.

Utilization of agro-industrial residues for the manufacturing of mycoprotein is another strategy that can be considered to decrease the environmental impact of this meat substitute. Lignocellulosic materials without pretreatment can be used by filamentous fungus for the production of mycoprotein in submerged culture as well as in solid-state fermentation (Satari and Karimi 2018). The challenge in this alternative is to find agro-industrial waste streams that have beneficial nutritional composition to guarantee an efficient production. Moreover, if such streams are currently used for animal feed, 
the environmental impact caused by the replacement of these materials in the animal production can lead to an increased environmental impact. The successful utilization of the agrifood waste in the production of mycoprotein could reduce the environmental impact to $2-4 \mathrm{~kg} \mathrm{CO}_{2 \mathrm{eq}}$, the use of land to $0.5 \mathrm{~m}^{2} \mathrm{a}$, and the consumption of water and energy to $250 \mathrm{~L}$ and $10 \mathrm{kWh}$, respectively, per $\mathrm{kg}$ of mycoprotein (Smetana et al. 2018). However, the implementation of this technology in an industrial scale needs to previously overcome remaining challenges such as regulatory and safety approval, scale up of production, and large-scale trials (Lee et al. 2015).

\section{Nutrition and health}

The human diet has rapidly changed over the last decades and our food is often suboptimal (Popkin et al. 2012). For food planning purposes, an appropriate protein intake should be of approximately $15 \mathrm{E} \%$ (i.e., $15 \%$ of the total energy intake). This corresponds to about $1.1 \mathrm{~g}$ of proteins per $\mathrm{kg}$ of body weight and day. For the elderly ( $\geq 65$ years), an appropriate goal should be $18 \mathrm{E} \%$, i.e., $1.2 \mathrm{~g}$ of proteins per kg of body weight and day (Nordic Council of Ministers 2014). An inadequate intake of proteins can result in edemas, muscle weakness, and detrimental changes in hair and skin (Nordic Council of Ministers 2014). Malnutrition over an extended period of time can lead to Protein-Energy Malnutrition (PEM) and result in serious diseases, such as kwashiorkor and marasmus (Batool et al. 2015).

Dunlop et al. (2017) investigated the impact of the mycoprotein ingestion on healthy young men, in a dose-response manner, on acute postprandial hyperaminoacidaemia and hyperinsulinaemia. The results demonstrated that the bioavailability of all amino acids (including the essential ones) in the mycoprotein is similar to milk and better than the plant-based protein sources. Additionally, an amount of $60 \mathrm{~g}$ of mycoprotein was determined to give an optimal response regarding muscle protein synthesis (Dunlop et al. 2017). Further research is needed in order to determine the optimal dose for various populations.

Mycoprotein is a low-fat, high-protein and high-fiber food component. On the other hand, its high RNA content raises some concerns. The fungal biomass originally contains $10 \%$ (dry weight) of RNA. Comparatively, edible offals such as beef liver and heart contain approximately 2 and $0.6 \%$ of RNA, respectively. Muscles contain even less (Jonas et al. 2001). The consumption of excessive quantities of RNA can lead to an increased amount of uric acid in the body, being therefore a risk factor for gout (Denny et al. 2008; Jonas et al. 2001). During its production, the biomass of Fusarium venenatum is submitted to a heat treatment. By rapidly heating the fungal biomass (still in the broth) to temperatures above $68^{\circ} \mathrm{C}$, and keeping it for 20-45 min, the RNA content of the mycoprotein is reduced to less than $2 \%$. The thermal treatment acts by degrading the RNA into monomers that diffuse out of the cells (Raats 2007).

The mycoprotein contains a little amount of sodium and is a good source of zinc, selenium and antioxidants (Denny et al. 2008; Smith et al. 2015); yet the levels of iron and vitamin B12 are low compared to those found in red meat (Denny et al. 2008). Whether or not iron or other substances can be added to the growth medium in order to produce an enriched mycoprotein, with increased bioavailability, is worthy of further study.

The fiber present in the mycoprotein is composed of two-thirds $\beta$-glucan and one-third chitin, creating a "fibrous chitin-glucan matrix" with low water solubility ( $88 \%$ insoluble) (Bottin et al. 2016). The chitin is a polymer formed by $\mathrm{N}$-acetylglucosamine monomers not commonly present in the human diet. Some potential effects the chitin ingestion causes in the health include the relief of joint pain in osteoarthritis and the stimulation of beneficial bacteria in the colon (Sadler 2004). Moreover, the mycoprotein's fibers appear to improve the glycemic profile in a not-completely understood mechanism (Bottin et al. 2016; Denny et al. 2008; Turnbull and Ward 1995). Bottin et al. (2016) studied the effect of the consumption of mycoprotein in overweight and obese volunteers. Three amounts of mycoprotein were tested $(44,88$ and $132 \mathrm{~g}$ per meal) and their results were compared to chicken meals containing the same energetic values. The ingestion of a meal containing mycoprotein improved the insulin sensitivity and decreased the insulin concentrations. Turnbull and Ward (1995) have reported that, for healthy individuals, the ingestion of mycoprotein has substantial effects on both glycemic and insulinemic variables $60 \mathrm{~min}$ after the meal, compared to a milk and soy flour option. More recently, Dunlop et al. (2017) also compared mycoprotein to milk in health subjects and concluded that the mycoprotein caused a slower but longer hyperinsulinaemia, i.e., the level of insulin in the blood increased less but was sustained for a longer period (the insulin peak was observed $45 \mathrm{~min}$ after the mycoprotein meal but only 15 min after the milk meal).

The consumption of mycoprotein possibly lowers the total blood cholesterol and the greatest benefits have been observed in subjects with raised cholesterol levels at baseline (Ruxton and McMillan 2010). Although an optimal intake of mycoprotein was not determined, the results suggest there might be a dose-dependent relationship (Denny et al. 2008). Additionally, compared to other protein sources such as chicken, the mycoprotein presents advantages regarding satiety (Bottin et al. 2016; Williamson et al. 2006). This might be due to the protein content as well as the fiber content, since both proteins and fibers have the ability to increase the feeling of satiety (Paddon-Jones et al. 2008; Slavin and Green 2007). It is possible that a diet including mycoprotein may fight hunger, reduce energy intake and facilitate weight loss. There is a need of longer-term studies with large 
sample sizes in order to fully understand the potential role of mycoprotein in relation to health and non-communicable diseases. More research is also needed to establish an optimal dose of mycoprotein to boost health for men, women, children, and older adults.

\section{Conclusion}

Human dietary habits have changed and deeply affected our health, environment and society. Climate-smart food systems can help to reduce the negative impacts of this sector. Accordingly, substitution of the meat by meat analogues can present beneficial results in both personal and societal aspects. Mycoprotein is an interesting source of good-quality proteins, with good acceptance among consumers, and proven positive impacts in cholesterol, sugar, and insulin blood levels. On the other hand, the high price of this meat substitute narrows its consumption to developed markets, and the raw materials used in the product formulation impose a high environmental impact compared to other vegetarian options. Hence, alternative production processes using agro-industrial residues as substrate and solid state fermentation have been the subject of investigation.

\section{Acknowledgment Open access funding provided by University of} Boras.

Open Access This article is distributed under the terms of the Creative Commons Attribution 4.0 International License (http://creativeco mmons.org/licenses/by/4.0/), which permits unrestricted use, distribution, and reproduction in any medium, provided you give appropriate credit to the original author(s) and the source, provide a link to the Creative Commons license, and indicate if changes were made.

\section{References}

Ahsan N, Rao RSP, Gruppuso PA, Ramratnam B, Salomon AR (2016) Targeted proteomics: current status and future perspectives for quantification of food allergens. J Proteom 143:15-23

Anupama, Ravindra P (2000) Value-added food: single cell protein. Biotechnol Adv 18:459-479

Asgar MA, Fazilah A, Huda N, Bhat R, Karim AA (2010) Nonmeat protein alternatives as meat extenders and meat analogs. Compr Rev Food Sci Food Saf 9:513-529. https://doi.org/10.111 1/j.1541-4337.2010.00124.x

Augustin MA, Riley M, Stockmann R, Bennett L, Kahl A, Lockett T, Osmond M, Sanguansri P, Stonehouse W, Zajac I, Cobiac L (2016) Role of food processing in food and nutrition security. Trends Food Sci Technol 56:115-125

Batool R, Butt MS, Sultan MT, Saeed F, Naz R (2015) Protein-energy malnutrition: a risk factor for various ailments. Crit Rev Food Sci Nutr 55:242-253

Bhat ZF, Fayaz H (2011) Prospectus of cultured meat—advancing meat alternatives. J Food Sci Technol 48(2):125-140

Boland MJ, Rae AN, Vereijken JM, Meuwissen MPM, Fischer ARH, van Boekel MAJS, Rutherfurd SM, Gruppen H, Moughan PJ,
Hendriks WH (2013) The future supply of animal-derived protein for human consumption. Trends Food Sci Technol 29:62-73

Bottin JH, Swann JR, Cropp E, Chambers ES, Ford HE, Ghatei MA, Frost GS (2016) Mycoprotein reduces energy intake and postprandial insulin release without altering glucagon-like peptide-1 and peptide tyrosine-tyrosine concentrations in healthy overweight and obese adults: a randomised-controlled trial. Br J Nutr 116:360-374

Claret A, Guerrero L, Gartzia I, Garcia-Quiroga M, Ginés R (2016) Does information affect consumer liking of farmed and wild fish? Aquaculture 454:157-162

Clune S, Crossin E, Verghese K (2017) Systematic review of greenhouse gas emissions for different fresh food categories. J Clean Prod 140:766-783

Denny A, Aisbitt B, Lunn J (2008) Mycoprotein and health nutrition. Bulletin 33:298-310. https://doi.org/10.111 1/j.1467-3010.2008.00730.x

Domingo JL (2016) Nutrients and chemical pollutants in fish and shellfish balancing health benefits and risks of regular fish consumption. Crit Rev Food Sci Nutr 56(6):979-988

Dunlop MV, Kilroe SP, Bowtell JL, Finnigan TJA, Salmon DL, Wall BT (2017) Mycoprotein represents a bioavailable and insulinotropic non-animal-derived dietary protein source: a dose-response study. Br J Nutr 118:673-685

Dunne JA, Williams RJ, Martinez ND (2002) Network structure and biodiversity loss in food webs: robustness increases with connectance. Ecol Lett 5:558-567. https://doi.org/10.104 6/j.1461-0248.2002.00354.x

Elzerman JE, Hoek AC, van Boekel MAJS, Luning PA (2011) Consumer acceptance and appropriateness of meat substitutes in a meal context. Food Qual Prefer 22:233-240

Emanuelsson A, Ziegler F, Pihl L, Sköld M, Sonesson U (2014) Accounting for overfishing in life cycle assessment: new impact categories for biotic resource use. Int J Life Cycle Assess 19(5):1156-1168

FAO (2010) 'Climate-smart' agriculture: Policies, practices and financing for food security, adaptation and mitigation. Food and Agriculture Organization, Rome

Fenko A, Backhaus BW, van Hoof JJ (2015) The influence of productand person-related factors on consumer hedonic responses to soy products. Food Qual Prefer 41:30-40

Finnigan T, Lemon M, Allan B, Paton I (2010) Mycoprotein, life cycle analysis and the food 2030 challenge. Asp Appl Biol 102:81-90

Godfray HCJ, Beddington JR, Crute IR, Haddad L, Lawrence D, Muir JF, Pretty J, Robinson S, Thomas SM, Toulmin C (2010) Food security: the challenge of feeding. Billion People Sci 327:812818. https://doi.org/10.1126/science. 1185383

Godfray HCJ, Aveyard P, Garnett T, Hall JW, Key TJ, Lorimer J, Pierrehumbert RT, Scarborough P, Springmann M, Jebb SA (2018) Meat consumption, health, and the environment. Science. https://doi.org/10.1126/science.aam5324

Grahl S, Palanisamy M, Strack M, Meier-Dinkel L, Toepfl S, Mörlein D (2018) Towards more sustainable meat alternatives: how technical parameters affect the sensory properties of extrusion products derived from soy and algae. J Clean Prod 198:962-971

Guinard J-X, Myrdal Miller A, Mills K, Wong T, Lee SM, Sirimuangmoon C, Schaefer SE, Drescher G (2016) Consumer acceptance of dishes in which beef has been partially substituted with mushrooms and sodium has been reduced. Appetite 105:449-459

Gul K, Singh P, Wani AA (2016) Chapter 4-Safety of meat and poultry. Regulating safety of traditional and ethnic foods. Academic Press, San Diego, pp 63-77

Hegde VL, Das JR, Venkatesh YP (2002) Anaphylaxis caused by the ingestion of cultivated mushroom (Agaricus bisporus): identification of allergen as mannitol. Allergol Int 51(2):121-129 
Hoek AC, Luning PA, Weijzen P, Engels W, Kok FJ, de Graaf C (2011) Replacement of meat by meat substitutes. A survey on personand product-related factors in consumer acceptance. Appetite 56:662-673

Huis A (2013) Potential of insects as food and feed in assuring food security. Annu Rev Entomol 58(1):563-583

Jacobson MF, DePorter J (2018) Self-reported adverse reactions associated with mycoprotein (Quorn-brand) containing foods. Ann Allergy Asthma Immunol 120(6):626-630

Johnston JL, Fanzo JC, Cogill B (2014) Understanding sustainable diets: a descriptive analysis of the determinants and processes that influence diets and their impact on health. Food Secur Environ Sustain Adv Nutr 5:418-429. https://doi.org/10.3945/ an.113.005553

Jonas DA, Elmadfa I, Engel KH, Heller KJ, Kozianowski G, König A, Müller D, Narbonne JF, Wackernagel W, Kleiner J (2001) Safety considerations of DNA in food. Ann Nutr Metab 45:235-254

Jungbluth N, Eggenberger S, Nowack K, Keller R (2016) Life cycle assessment of meals based on vegetarian protein sources. In proceedings from: the 10th international conference on life cycle assessment of food (LCA Food 2016).

Kucuk O (2017) Soy foods, isoflavones, and breast cancer. Cancer 123(11):1901-1903

Kumar P, Chatli MK, Mehta N, Singh P, Malav OP, Verma AK (2017) Meat analogues: health promising sustainable meat substitutes. Crit Rev Food Sci Nutr 57(5):923-932

Lee JZ, Logan A, Terry S, Spear JR (2015) Microbial response to single-cell protein production and brewery wastewater treatment. Microb Biotechnol 8:65-76

Marlow Foods Ltd. (2019). https://www.quorn.co.uk/recipes. Accessed 03 Apr 2019

Matassa S, Boon N, Pikaar I, Verstraete W (2016) Microbial protein: future sustainable food supply route with low environmental footprint. Microb Biotechnol 9(5):568-575

Meinlschmidt P, Ueberham E, Lehmann J, Schweiggert-Weisz U, Eisner P (2016) Immunoreactivity, sensory and physicochemical properties of fermented soy protein isolate. Food Chem 205:229-238

Mleczek M, Niedzielski P, Siwulski M, Rzymski P, Gąsecka M, Goliński P, Kozak L, Kozubik T (2016) Importance of low substrate arsenic content in mushroom cultivation and safety of final food product. Eur Food Res Technol 242(3):355-362

Moore D, Chiu SW (2001) Fungal products as food. In Pointing, SB and Hyde, KD (eds) Bio-exploitation of filamentous fungi. Fungal Divers Res Ser 6:223-251.

Niksic M, Klaus A, Argyropoulos D (2016) Chapter 22-Safety of foods based on mushrooms. Regulating safety of traditional and ethnic foods. Academic Press, San Diego, pp 421-439

Nordic Council of Ministers (2014) Nordic Nutrition Recomendations 2012 - integrating nutrition and physical activity, Copenhagen 5(11):1

Nout MJR, Aidoo KE (2002) Asian fungal fermented food. In: Industrial Applications. Springer, New York, pp 23-47

Paddon-Jones D, Westman E, Mattes RD, Wolfe RR, Astrup A, Westerterp-Plantenga M (1561S) Protein, weight management, and satiety. Am J Clin Nutr 87:1558S-1561S. https://doi.org/10.1093/ ajcn/87.5.1558S

Pan AP, Sun QMDS, Bernstein AMMDS, Schulze MBD, Manson JEMDD, Stampfer MJMDD, Willett WCMDD, Hu FBMDP (2012) Red meat consumption and mortality: results from 2 prospective cohort studies. Arch Int Med 172:555-563

Pereira PMCC, Vicente AFRB (2013) Meat nutritional composition and nutritive role in the human diet. Meat Sci 93(3):586-592

Petracci M, Berri C (2017) Poultry quality evaluation: quality attributes and consumer values. Woodhead Publishing, Duxford
Piazza J, Ruby MB, Loughnan S, Luong M, Kulik J, Watkins HM, Seigerman M (2015) Rationalizing meat consumption. The 4Ns. Appetite 91:114-128

Popkin BM, Adair LS, Ng SW (2012) Global nutrition transition and the pandemic of obesity in developing countries. Nutr Rev 70:321. https://doi.org/10.1111/j.1753-4887.2011.00456.x

Post MJ (2012) Cultured meat from stem cells: challenges and prospects. Meat Sci 92(3):297-301

Raats J (2007) Meat (substitutes) comparing environmental impacts. A Case study comparing Quorn and pork, University of Groningen

Ritchie H, Laird J, Ritchie D (2017) 3f bio: Halving the cost of mycoprotein through integrated fermentation processes. Ind Biotechnol 13:29-31

Rohrmann S, Overvad K, Bueno-de-Mesquita HB, Jakobsen MU, Egeberg R, Tjønneland A, Nailler L, Boutron-Ruault M-C, ClavelChapelon F, Krogh V, Palli D, Panico S, Tumino R, Ricceri F, Bergmann MM, Boeing H, Li K, Kaaks R, Khaw K-T, Wareham NJ, Crowe FL, Key TJ, Naska A, Trichopoulou A, Trichopoulos D, Leenders M, Peeters PHM, Engeset D, Parr CL, Skeie G, Jakszyn P, Sánchez M-J, Huerta JM, Redondo ML, Barricarte A, Amiano P, Drake I, Sonestedt E, Hallmans G, Johansson I, Fedirko V, Romieux I, Ferrari P, Norat T, Vergnaud AC, Riboli E, Linseisen J (2013) Meat consumption and mortality—results from the European Prospective Investigation into Cancer and Nutrition. BMC Med 11:63. https://doi.org/10.1186/1741-7015-11-63

Röös E, Sundberg C, Tidåker P, Strid I, Hansson P-A (2013) Can carbon footprint serve as an indicator of the environmental impact of meat production? Ecol Ind 24:573-581

Ruxton CHS, McMillan B (2010) The impact of mycoprotein on blood cholesterol levels: a pilot study. Br Food J 112:1092-1101

Rzymski P, Niedzielski P, Kaczmarek N, Jurczak T, Klimaszyk P (2015) The multidisciplinary approach to safety and toxicity assessment of microalgae-based food supplements following clinical cases of poisoning. Harmful Algae 46:34-42

Sadler MJ (2004) Meat alternatives-market developments and health benefits. Trends Food Sci Technol 15:250-260

Satari B, Karimi K (2018) Mucoralean fungi for sustainable production of bioethanol and biologically active molecules. Appl Microbiol Biotechnol 102:1097-1117. https://doi.org/10.1007/s0025 3-017-8691-9

Scott LW, Dunn JK, Pownall HJ, Brauchi DJ, McMann MC, Herd JA, Harris KB, Savell JW, Cross HR, Gotto AM Jr (1994) Effects of beef and chicken consumption on plasma lipid levels in hypercholesterolemic men. JAMA Intern Med 154(11):1261-1267

Siegrist M, Hartmann C (2019) Impact of sustainability perception on consumption of organic meat and meat substitutes. Appetite 132:196-202

Slavin J, Green H (2007) Dietary fibre and satiety. Nutr Bull 32:32-42

Smetana S, Mathys A, Knoch A, Heinz V (2015) Meat alternatives: life cycle assessment of most known meat substitutes. Int J Life Cycle Assess 20:1254-1267. https://doi.org/10.1007/s1136 7-015-0931-6

Smetana S, Aganovic K, Irmscher S, Heinz V (2018) Agri-food waste streams utilization for development of more sustainable food substitutes. Designing sustainable technologies, products and policies: from science to innovation. Springer, Cham, pp 145-155

Smith H, Doyle S, Murphy R (2015) Filamentous fungi as a source of natural antioxidants. Food Chem 185:389-397

Snowdon DA, Phillips RL, Fraser GE (1984) Meat consumption and fatal ischemic heart disease. Prev Med 13:490-500

Sonesson U, Davis J, Flysjö A, Gustavsson J, Witthöft C (2017) Protein quality as functional unit-a methodological framework for inclusion in life cycle assessment of food. J Clean Prod 140:470-478 
Steinfeld H, Gerber P, Wassenaar TD, Castel V, Rosales M, Rosales M, de Haan C (2006) Livestock's long shadow: environmental issues and options. Food \& Agriculture Org

Tscharntke T, Clough Y, Wanger TC, Jackson L, Motzke I, Perfecto I, Vandermeer J, Whitbread A (2012) Global food security, biodiversity conservation and the future of agricultural intensification. Biol Conserv 151:53-59

Turnbull WH, Ward T (1995) Mycoprotein reduces glycemia and insulinemia when taken with an oral-glucose-tolerance test. Am J Clin Nutr 61:135-140. https://doi.org/10.1093/ajen/61.1.135

Weinrich R, Elshiewy O (2019) Preference and willingness to pay for meat substitutes based on micro-algae. Appetite 142:104353

Wiebe M (2002) Myco-protein from Fusarium venenatum: a wellestablished product for human consumption. Appl Microbiol Biotechnol 58:421-427. https://doi.org/10.1007/s00253-002-0931-x
Williamson DA, Geiselman PJ, Lovejoy J, Greenway F, Volaufova J, Martin CK, Arnett C, Ortego L (2006) Effects of consuming mycoprotein, tofu or chicken upon subsequent eating behaviour, hunger and safety. Appetite 46:41-48

Wouters AG, Rombouts I, Lagrain B, Delcour JA (2016) Impact of casein and egg white proteins on the structure of wheat glutenbased protein-rich food. J Sci Food Agric 96:757-763

Publisher's Note Springer Nature remains neutral with regard to jurisdictional claims in published maps and institutional affiliations. 